
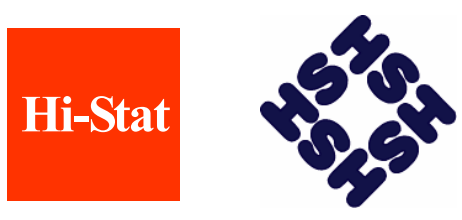

Discussion Paper Series

No.181

\title{
Information Technology and \\ The World Growth Resurgence
}

Dale W. Jorgenson

Khuong Vu

August 2006

Hitotsubashi University Research Unit for Statistical Analysis in Social Sciences A 21st-Century COE Program

Institute of Economic Research Hitotsubashi University Kunitachi, Tokyo, 186-8603 Japan http://hi-stat.ier.hit-u.ac.jp/ 


\section{Title: INFORMATION TECHNOLOGY AND THE WORLD GROWTH RESURGENCE}

Authors: Dale W. Jorgenson

Harvard University

djorgenson@harvard.edu

and

Khuong $\mathrm{Vu}$

National University of Singapore

sppkmv@nus.edu.sg

Abstract: This paper analyzes the impact of investment in information technology (IT) on the recent resurgence of world economic growth. We describe the growth of the world economy, seven regions, and fourteen major economies during the period 1989-2004. We allocate the growth of world output between input growth and productivity and find, surprisingly, that input growth greatly predominates! Moreover, differences in per capita output levels are explained by differences in per capita input, rather than variations in productivity. The contributions of IT investment have increased in all regions, but especially in industrialized economies and Developing Asia.

Key words: growth, investment, productivity, information technology. JEL classification: 047. 


\section{INFORMATION TECHNOLOGY AND THE WORLD GROWTH RESURGENCE*}

\section{by}

\section{Dale W. Jorgenson and Khuong Vu}

\section{Introduction.}

The purpose of this paper is to analyze the impact of investment in information technology (IT) equipment and software on the recent revival of world economic growth. The crucial role of IT investment in the growth of the U.S. economy has been thoroughly documented and widely discussed. ${ }^{1}$ Jorgenson (2001) has shown that the remarkable behavior of IT prices is the key to understanding of the American growth resurgence since 1995. This behavior can be traced to developments in semiconductor technology that are widely understood by technologists and economists.

Jorgenson (2003) has shown that the growth of IT investment jumped to double-digit levels after 1995 in all the G7 economies - Canada, France, Germany, Italy, Japan, and the United Kingdom, as well as the United States. ${ }^{2}$ These economies account for nearly half of world output and a much

\footnotetext{
"Department of Economics, Harvard University, 122 Littauer Center, Cambridge, MA 02138-3001. The Economic and Social Research Institute provided financial support for work on the $\mathrm{G} 7$ economies from its program on international collaboration through the Nomura Research Institute. Alessandra Colecchia, Mun S. Ho, Kazuyuki Motohashi, Koji Nomura, Jon Samuels, Kevin J. Stiroh, Marcel Timmer, Gerard Ypma, and Bart van Ark provided valuable data. The Bureau of Economic Analysis and the Bureau of Labor Statistics assisted with data for the U.S and Statistics Canada contributed the data for Canada. We are grateful to all of them but retain final responsibility for any remaining deficiencies.

${ }^{1}$ See Jorgenson and Kevin Stiroh (2000) and Stephen Oliner and Daniel Sichel (2000). The growth accounting methodology employed in this literature is discussed by Jorgenson, Mun Ho, and Stiroh (2005) and summarized by Jorgenson (2005).

${ }^{2}$ Nadim Ahmad, Paul Schreyer, and Anita Wolfl (2004) have analyzed the impact of IT investment in OECD countries. Timmer, et al., (2003, 2005) and Francesco Daveri (2002) have presented comparisons among European economies. Marcin Piatkowski and van Ark (2005) have compared the impact of IT investment on the economies of Eastern Europe and the former Soviet Union.
} 
larger share of world IT investment. The surge of IT investment resulted from a sharp acceleration in the rate of decline of prices of IT equipment and software. Jorgenson (2001) has traced this to a drastic shortening of the product cycle for semiconductors from three years to two years, beginning in 1995.

In Section 2 we describe the growth of the world economy, seven economic regions, and fourteen major economies during the period 1989-2004. ${ }^{3}$ The world economy is divided among the G7 and Non-G7 industrialized economies, Developing Asia, Latin America, Eastern Europe and the former Soviet Union, North Africa and the Middle East, and Sub-Saharan Africa. The fourteen major economies include the $\mathrm{G} 7$ economies listed above and the developing and transition economies of Brazil, China, India, Indonesia, Mexico, Russia, South Korea.

We have sub-divided the period 1989-2004 into 1989-1995, 1995-2000, and 2000-2004 in order to focus on the response of IT investment to the accelerated decline in IT prices in 1995 and the impact of the dot-com crash of 2000. World economic growth has undergone a powerful revival since 1995 . The per capita growth rate jumped a full percentage point from 2.72 percent during 1989-1995 to 3.73 percent in 1995-2000 and higher growth was sustained at a rate of 3.75 percent after 2000 . We can underscore the significance of more rapid growth by pointing out that per capita growth of 2.72 percent doubles world output by four times in a century, while 3.75 percent doubles output more than five times per century.

In Section 3 we allocate the growth of world output between input growth and productivity. Our most astonishing finding is that input growth greatly predominates! Productivity growth accounted for less than one-fifth

\footnotetext{
${ }^{3}$ We include 110 economies with more than one million in population and a complete set of national accounts for the period 1989-2004 from Penn World Table (2002) and World Bank Development Indicators Online (2006). These economies account for more that 96 percent of world output.
} 
of the total during 1989-1995, while input growth accounted for more than four-fifths. Similarly, input growth contributed almost three-quarters of growth from 1995-2000 and more than three-fifths from 2000-2004. The only departure from this world-wide trend was the revival of economic growth in Eastern Europe after 1995, driven by a rebound from the productivity collapse of 1989-1995.

In Section 3 we distribute the growth of input per capita between investments in human capital and tangible assets, especially IT equipment and software. The world economy, all seven regions, and the fourteen major economies experienced a surge in investment in IT after 1995. The soaring level of U.S. IT investment after 1995 was paralleled by jumps in IT investment throughout the industrialized world. The contributions of IT investment in Developing Asia, Latin America, Eastern Europe, North Africa and the Middle East, and Sub-Saharan Africa more than doubled after 1995, beginning from much lower levels.

The contribution of IT investment to growth of the G7 economies has moderated substantially since the dot-com crash of 2000 . The IT contribution has slowed for the Non-G7 industrialized economies as well. However, the contribution of IT investment has continued to rise for Developing Asia, Latin America, Eastern Europe, North Africa and the Middle East, and SubSaharan Africa. The contributions of Non-IT investment and labor input to world growth declined after the dot-com crash, but total factor productivity growth rose substantially, reflecting increases in all regions except North Africa and the Middle East.

In Section 4 we present levels of output per capita, input per capita, and productivity for the world economy, the seven economic regions, and the fourteen major economies. We find that differences in per capita output levels are primarily explained by differences in per capita input, rather than variations in productivity. Taking U.S. output per capita in 2000 as 
100.๑, world output per capita was a relatively modest 24.9 in 2004 . Using similar scales for input and productivity, world input per capita in 2004 was a substantial 37.7 and world productivity a robust 66.0 . Section 5 concludes the paper.

\section{World Economic Growth, 1989-2004.}

In order to set the stage for analyzing the impact of IT investment on the growth of the world economy, we first consider the shares of world product and growth for the seven regions and fourteen major economies presented in Table 1. Following Jorgenson (2001), we have chosen GDP as a measure of output. We employ the Penn World Table, presented by Alan Heston, Robert Summers, and Bettina Aten (2002), as the primary data source on GDP and purchasing power parities for economies outside the G7 and the European Union prior to enlargement in May $2004 .^{4}$

We have revised and updated the U.S. data presented by Jorgenson (2001) through 2004. Comparable data for Canada have been constructed by Statistics Canada. ${ }^{5}$ Data for France, Germany, Italy, and the U.K. and the economies of the European Union before enlargement have been developed for the European Commission by Timmer, et al. ${ }^{6}$ Finally, data for Japan have been assembled by Jorgenson and Motohashi for the Research Institute on Economy, Trade, and Industry. ${ }^{7}$ We have linked these data by means of the OECD'S purchasing power parities for $2002 .^{8}$

The G7 economies accounted for slightly under half of world product from 1989-1995. The per capita growth rates of these economies - 2.19 percent before 1995, 3.25 percent from 1995-2000, and 2.20 percent during

\footnotetext{
${ }^{4}$ Maddison (2001) provides estimates of national product and population for 134 countries for varying periods from 1820-1998 in his magisterial volume, The World Economy: A Millenial Perspective.

${ }^{5}$ See Baldwin and Harchaoui (2003).

${ }^{6}$ See Timmer, Ypma, and van Ark (2003, updated 2005).

${ }^{7}$ See Jorgenson and Motohashi (2005).

${ }^{8}$ See OECD (2005).
} 
2000-2004 - lagged considerably behind world growth rates for these periods. The G7 shares in world growth were 39.7 percent during 1989-1995 and 41.2 percent from 1995-2000, but only a meager 26.4 percent during 2000-2004. This led to a decline of four percentage points in the $\mathrm{G} 7$ share of world product from 49 percent in 1989-1995 to 45 percent during 2000-2004.

During 1989-1995 the U.S. accounted for 22.9 percent of world product and 46.6 percent of $\mathrm{G} 7$ product. The U.S. share of $\mathrm{G} 7$ output rose to 47.9 percent from 1995-200๑ and 49.6 percent during 2000-2004. After 1995 Japan fell from its ranking as the world's second largest economy to third largest after China, but remained second among the G7 economies. Germany dropped from fourth place before 1995, following the U.S., China, and Japan, to fifth place after 1995, ranking behind India as well. However, Germany retained its position as the leading European economy. France, Italy and the U.K. were considerably smaller, but similar in size. Canada was the smallest of the $G 7$ economies.

The U.S. growth rate jumped from 2.44 percent during 1989-1995 to 4.29 percent in 1995-2000, before subsiding to 2.75 percent from 2000-2004. The period 2000-2004 includes the dot-com crash of 2000, the shallow U.S. recession of 2001, and the recovery that followed, while the period 19952000 encompasses the IT-generated investment boom of the last half of the $1990^{\prime}$ 's. The U.S. share in world growth exceeded its share in world product only during 1995-2000. The remaining G7 economies had lower shares of world growth than world product throughout the period 1989-2004.

The 16 economies of Developing Asia generated only slightly more than a fifth of world output before 1995, but 24.4 percent from 1995-2000 and a stunning 27.3 percent after 2000! The burgeoning economies of China and India accounted for more than 60 percent of Asian output during 1989-1995, 
65 percent in 1995-2000, and 68.6 percent after $2000 .{ }^{9}$ The economies of Developing Asia grew at 7.54 percent before 1995, 5.91 percent from 1995 2000 , and 6.51 percent after 2000 . These economies generated an astounding 55.7 percent of world growth during the remarkable revival of 1989-1995! Developing Asia's share in world growth declined to 38.7 percent during 1995-2000, below the G7 share of 41.2 percent, but recovered to 47.5 percent after 2000. China alone accounted for more than a quarter of world growth during the period 1989-2004.

The 15 Non-G7 industrialized economies generated 9.2 percent of world output during 1989-1995. However, these economies had lower shares in world growth than world product throughout the period 1989-2004. Their shares in world output dropped to nine percent during 1995-2000 and 8.7 percent after 2000. All of the economies of Eastern Europe experienced a decline in output during 1989-1995 after initiating the transition from socialism to a market economy. Collectively, these economies reduced world growth by 17.5 percent during the period 1989-1995, lowering their share of world product by almost two percentage points from 7.5 percent during 1989-1995 to 5.5 percent in 1995-2000 and 5.6 percent after 2000.

During 1989-1995 the 9.2 percent share of the Latin American economies in world growth exceeded their 8.7 percent share in world product. Growth in these economies declined to 4.6 percent of world growth in 1995-2000 and revived modestly to 6.2 percent after 2000. Brazil and Mexico were responsible for about sixty percent of Latin American GDP throughout the period 1989-2004. However, the shares of these two major Latin American

\footnotetext{
${ }^{9}$ Our data for China are taken from the Penn World Table (2002). These data are based on Maddison (1998) rather than official Chinese estimates. Maddison and Alwyn Young (2003) present persuasive evidence that the official estimates exaggerate the growth of output and productivity in China. For extensive references to the debate over Chinese growth rates and a review of the issues, see the recent critique of Maddison by Carsten Holz (2006) and Maddison's (2006) reply.
} 
economies in world product fell below their growth shares, leading to gradual declines in their product shares from 5.3 percent in 1989-1995, to five percent during 1995-2000, and 4.8 percent after 2000.

The 11 economies of North Africa and the Middle East, taken together, were comparable in size to France, Italy, or the U.K., while the 30 economies of Sub-Saharan Africa, as a group, ranked with Canada. The economies of North Africa and the Middle East had a share in world growth of 4.6 percent during 1989-1995, well above their 3.2 percent share in world product. During 1995-2000 their share in world growth fell to 3.5 percent, still above the corresponding share in world product of 3.3 percent. This trend continued with a growth share of 3.9 percent and a product share of 3.4 percent after 2000 . Growth shares in the economies of Sub-Saharan Africa lagged behind their shares in world product before 2000, but the two shares were essentially the same after 2000.

\section{Sources of World Economic Growth.}

In this section we allocate the sources of world economic growth among the contributions of capital and labor inputs and the growth of productivity. About 35-40 percent of world growth can be attributed to the accumulation and deployment of capital and another a quarter to a third to the more effective use of labor. We find that productivity, frequently described as the primary engine of economic growth, accounted for only $20-40$ percent of growth.

We have derived estimates of capital input and property income from national accounting data for the G7 economies. We have constructed estimates of hours worked and labor compensation from labor force surveys for each of these economies. We measure the contribution of labor inputs, classified by age, sex, educational attainment, and employment status, by weighting the growth rate of each type of labor input by its share in the value of output. Finally, we employ purchasing power parities for capital and labor inputs 
constructed by Jorgenson (2003). ${ }^{10}$ We have extended these estimates of capital and labor inputs to the 103 Non-G7 countries using data sources and methods described in the Appendix to the electronic version of the paper. ${ }^{11}$ Our second objective is to explore the determinants of the growth of capital input, emphasizing the role of investment in information technology equipment and software. We have derived estimates of IT investment from national accounting data for the $\mathrm{G} 7$ and the economies of the European Union before enlargement. We measure the contribution of IT investment to economic growth by weighting the growth rate of IT capital input by its share in the value of output. Similarly, the contribution of Non-IT investment is a share-weighted growth rate of Non-IT capital input. The contribution of capital input is the sum of these two components.

We have revised and updated the U.S. data presented by Jorgenson (2001) on investment in information technology and equipment. ${ }^{12}$ Data on IT investment for Canada have been have been constructed by Statistics Canada. ${ }^{13}$ Data for the countries of the European Union have been developed for the European Commission by Timmer, et al. ${ }^{14}$ Finally, data for Japan have been assembled by Jorgenson and Motohashi. ${ }^{15}$ we have relied on the WITSA

\footnotetext{
10 Purchasing power parities for inputs follow the methodology described in detail by Jorgenson and Eric Yip (2001).

${ }^{11}$ We employ data on educational attainment from Robert Barro and Jong-Wha Lee (2001) and governance indicators constructed by Daniel Kaufmann, Aart Kraay, and Massimo Mastruzzi (2004) for the World Bank; for further details, see the electronic version of the paper: http://post. economics.harvard.edu/faculty/jorgenson/papers/papers.html. 12 U.S. data on investment in IT equipment and software, provided by the Bureau of Economic Analysis (BEA), are the most comprehensive and detailed. The BEA data are described by Bruce Grimm, Brent Moulton, and David Wasshausen (2005).

${ }^{13}$ See Baldwin and Harchaoui (2003).

${ }^{14}$ See Timmer, Ypma, and van Ark (2003, updated 2005).

${ }^{15}$ See Jorgenson and Motohashi (2005).
} 
Digital Planet Report (2006), as the starting point for estimates of IT investment for the remaining economies. ${ }^{16}$

Our third objective is to analyze the determinants of the growth of labor input, focusing on the role of investment in human capital. We have divided labor input growth between the growth of hours worked and labor quality, where quality is defined as the ratio of labor input to hours worked. Labor quality growth captures the impact of changes in the composition of labor input. These arise, for example, through increases in the education and experience of the labor force. The contribution of labor input is the sum of the two components, weighted by the share of labor in output. Finally, productivity growth is the difference between the rate of growth of output and the contributions of capital and labor inputs.

The contribution of capital input to world economic growth before 1995 was 1.13 percent, more than 41.5 percent of the growth rate of 2.72 percent. Labor input contributed one percent or slightly less than 36.4 percent of growth, while productivity growth was 0.61 percent per year or just over 22.4 percent of growth. During 1995-2000 the contribution of capital input climbed to 1.51 percent, nearly 40.5 percent of output growth of 3.73 percent, while the contribution of labor input rose to 1.27 percent, around 34 percent. Productivity increased to 0.96 percent per year or 25.7 percent of growth.

After 2000 world growth continued at an accelerated rate of 3.75 percent. The contribution of capital declined to 1.28 percent or 34.2 percent of the world growth. The contribution of labor fell to 1.07 percent

\footnotetext{
${ }^{16}$ WITSA stands for the World Information Technology and Services Alliance. other important sources of data include the International Telecommunication Union (ITU) telecommunications indicators, the UNDP Human Development reports, and the Business Software Alliance (2003). Additional details are given in the Appendix to the electronic version of this paper: http://post. economics. harvard.edu/faculty/jorgenson/papers/papers. html.
} 
or 28.5 percent of growth. More rapid growth was maintained by a jump in productivity growth to 1.4 percent per year or 37.3 percent of the growth of output. We arrive at the astonishing conclusion that the contributions of capital and labor inputs greatly predominate over productivity as sources of world economic growth throughout the period 1989-2004!

We have divided the contribution of capital input to world economic growth between IT equipment and software and Non-IT capital input. The contribution of IT almost doubled after 1995 from less than a quarter of the contribution of capital input during 1989-1995 to well over a third from 1995-2000. The share of IT in the contribution of capital input receded to slightly less than a third after the dot-com crash of 2000 . However, it is important to emphasize that the contribution of Non-IT investment was more important throughout the period 1989-2004.

We have divided the contribution of labor input between hours worked and labor quality. Hours worked was the major source of the contribution of labor input to economic growth throughout the period 1989-2004. The contribution of hours rose from 0.53 percent before 1995 to 0.92 percent during 1995-2000, but fell back to 0.70 percent after 2000 . The contribution of labor quality declined steadily from 0.45 percent before 1995 to 0.34 percent during 1995-2000 and to $\odot .37$ percent after 2000 .

After 1995 world economic growth jumped by a full percentage point. The contribution of capital explained $\odot .38$ percent of this acceleration, while productivity growth accounted for $\odot .35$ percent, and labor contributed 0.28 percent. The jump in IT investment of 0.29 percent was by far the most important source of the increase in capital. This can be traced to the more rapid rate of decline of IT prices after 1995 analyzed by Jorgenson (2001). The substantial increase of 0.39 percent in the contribution of hours worked offset the decline in the contribution of labor quality. 
Table 2 presents the contribution of capital input to economic growth for the G7 economies, divided between IT and Non-IT. Capital input was the most important source of growth before and after 1995. The contribution of capital input before 1995 was 1.28 or almost three-fifths of the G7 growth rate of 2.19 percent. The capital contribution of 1.69 percent from 19952000 was 52 percent of the higher growth rate of 3.25 percent. After 2000 the capital contribution fell to 1.05 percent or 47.7 percent of the substantially lower G7 growth rate of 2.20 percent.

Labor input growth contributed $\odot .50$ percent to growth of the G7 economies before 1995, $\odot .87$ percent in $1995-2000$, but only 0.36 percent after 2000. Hours worked predominated during 1995-2000, growing at 0.63 percent, while labor quality rose at 0.24 percent. Growth in hours was only 0.07 percent before 1995 and 0.28 percent after 2000, while labor quality growth was 0.43 percent and 0.17 percent, respectively. Productivity accounted for $\odot .42$ percent before 1995, $\odot .69$ percent during 1995-2000, and 0.79 percent after 2000 . Productivity ranged from less than 20 percent before 1995 to 36 percent after 2000.

The powerful surge of IT investment in the U.S. after 1995 is mirrored in jumps in the growth rates of IT capital through the G7. The contribution of IT capital input for the G7 more than doubled from 0.39 during the period 1989-1995 to 0.82 percent during 1995-2004, before receding to 0.47 percent after 2000 . The contribution of Non-IT capital input predominated in all three sub-periods, but fell steadily throughout 1989-2004. This reflected more rapid substitution of IT capital input for Non-IT capital input in response to swiftly declining prices of IT equipment and software after 1995.

In Developing Asia the contribution of capital input increased from 1.81 percent before 1995 to 2.22 percent in 1995-2000 and rose again to 2.27 percent after 2000 . The contribution of labor input fell from 2.33 percent 
during 1989-1995 to 1.64 percent during 1995-2000 and recovered slightly to 1.68 percent after 2000 . The significant slowdown in the Asian growth rate from 7.54 percent before 1995 to 5.91 percent during 1995-2000 can be traced almost entirely to a sharp decline in productivity growth from 3.41 to 2.04 percent. Similarly, the modest revival of growth to 6.51 percent can be attributed to higher productivity growth of 2.57 percent. Productivity explained slightly over 45 percent of Asian growth before 1995, less than 35 percent in 1995-2000, and around 40 percent after 2000.

The first half of the 1990's was a continuation of the Asian Miracle, analyzed by Paul Krugman (1994), Lawrence Lau (1999), and Young (1995). This period was dominated by the spectacular rise of China and India and the continuing emergence of the Gang of Four - Hong Kong, Singapore, South Korea, and Taiwan. However, all Asian economies, except The Philippines, had growth rates in excess of the world average of 2.72 percent. The second half of the 1990's was dominated by the Asian financial crisis but, surprisingly, conforms much more closely to the "Krugman thesis" attributing Asian growth to input growth rather than productivity.

The "Krugman thesis" was originally propounded to distinguish the Asian Miracle from growth in industrialized countries. According to this thesis, Asian growth was differentiated by high growth rates and a great predominance of inputs over productivity as the sources of growth. In fact, the peak of productivity growth in Developing Asia, absolutely and relatively, was during the Asian Miracle of the early 1990's! Moreover, growth in the world economy and the G7 economies was dominated by growth of capital and labor inputs, not productivity.

Developing Asia experienced a steady increase in the contribution of investment in IT equipment and software to economic growth. The contribution of IT investment more than doubled from 0.14 percent before 1995 to 0.33 during 1995-2000. The contribution of IT investment increased to 0.44 
percent after 2000. The rush in IT investment was particularly powerful in China, rising from 0.17 percent before 1995 to 0.48 percent during 1995-2000 and increasing again to 0.63 percent after 2000 . India lagged substantially behind China and the rest of Developing Asia as well.

Indonesia was the only major economy to experience a decline in the contribution of both IT and Non-IT investment during 1995-2000, the period of the Asian financial crisis. Indonesia's IT investment recovered slightly after 2000, but Non-IT investment continued to slump. South Korea's IT investment increased from $\odot .21$ before 1995 to $\odot .34$ in $1995-200 \odot$ and $\odot .39$ after 2000, while Non-IT investment dropped as a consequence of the financial crisis. The contribution of Non-IT investment in Asia greatly predominated throughout the period 1989-2004 and the contribution of hours worked outweighed labor quality as a source of growth in labor input.

The pattern of economic growth in the fifteen Non-G7 industrialized economies was similar to $G 7$ growth before 2000 with a sharp acceleration after 1995. However, the Non-G7 economies maintained rapid growth after 2000, while the $\mathrm{G} 7$ economies reverted to pre-1995 growth rates. The contribution of labor input predominated over capital input throughout the period 1989-2004. Non-G7 productivity growth fell from 0.85 percent before 1995 to 0.23 percent in 1995-2000, before rebounding to 0.37 percent after 2000 . Productivity accounted for more than 40 percent of growth before 1995, but less than eight percent from 1995-2000 and less than 13 percent after 2000.

The impact of investment in IT equipment and software in the Non-G7 economies doubled from 0.14 percent before 1995 to 0.31 percent during 1995 2000 , before falling back to 0.27 percent after 2000 . This provided a substantial impetus to the acceleration in Non-G7 growth rates in the face of sharply declining productivity growth. Non-IT investment explained an important part of the growth acceleration. However, the increased 
contribution of hours worked from $\odot .4 \odot$ percent before 1995 to 1.60 in 1995 2000 and 1.48 percent after 2000 greatly predominated.

The collapse of economic growth in Eastern Europe and the former Soviet Union during 1989-1995 can be attributed to a steep decline in productivity during the initial transition from socialism. This was followed by a modest revival in both economic growth and productivity growth from 1995-2000, bringing many of the transition economies back to 1989 levels of output per capita. The contribution of capital input declined throughout the period 1989-2004, even as the contribution of IT investment jumped from 0.09 percent before 1995 to 0.23 percent in $1995-2000$ and 0.31 percent after 2000. Hour worked declined sharply during 1989-1995 and continued to fall after 1995, but labor quality improved substantially.

Latin America's growth decelerated slightly after 1995, falling from 2.92 to 2.02 percent in 1995-2000, before recovering to 2.94 percent after 2000 . The contribution of labor input was 1.77 percent before $1995,1.70$ from 1995-2000 and 1.82 percent after 2000, accounting for the lion's share of regional growth. The contribution of capital input shifted toward IT, but remained relatively weak. Nonetheless, the contribution of IT investment in Latin America more than doubled, jumping from 0.14 percent before 1995 to 0.29 percent in 1995-2000 and $\odot .30$ after 2000 . Productivity collapsed after 1995, falling to a negative 0.62 percent in $1995-2000$, before recovering to 0.25 percent after 2000 .

Productivity in Sub-Saharan Africa collapsed during 1989-1995, running at -1.62 percent, before recovering to 0.24 percent in $1995-2000$ and rising sharply to 0.88 percent after 2000 . As in Latin America, the contribution of labor input predominated throughout the period 1989-2004. Productivity in North Africa and the Middle East dropped from 0.51 percent before 1995 to ๑.37 percent in 1995-2000 and $\odot .34$ percent after 2000. In Sub-Saharan Africa 
and North Africa and the Middle East, growth of capital and labor inputs greatly predominated over productivity as a source of economic growth.

\section{World Output, Input, and Productivity.}

The final step in analyzing the world growth resurgence is to characterize the evolution of levels of output, input, and productivity for the world economy, the seven economic regions, and the fourteen major economies. In Table 3 we present levels of output per capita when the transition from socialism began in 1989, at the start of the worldwide IT investment boom in 1995, at the beginning of the dot-com crash in 2000, and at the end of the period covered by our study in 2004 . We also present input per capita and productivity for these years, where productivity is defined as the ratio of output to input.

Differences in per capita output levels are mainly due to differences in per capita input, rather than disparities in productivity. Taking U.S. output per capita in 2000 as 100.0 , world output per capita was a relatively modest 18.6 in 1989. Using similar scales for input and productivity, world input per capita in 1989 was a considerable 30.5 and world productivity a very substantial 61.0 . The level of world output advanced to 19.9 in 1995, jumped to 22.4 in 2000 , and leapt again to 24.9 in 2004 , reflecting impressive progress in mobilizing world inputs. World productivity edged upward modestly to 61.2 in 1995, bounded to 63.5 in 2000 and then rose again to 66.0 in 2004 .

It is not surprising that world productivity is much closer to U.S. levels than world input per capita. As globalization has proceeded, technologies have been transferred with relative ease from industrialized economies to the developing world. Mobilization of inputs in developing economies has been remarkable, but has required far more time and effort. Institutional barriers to accumulation of human and non-human capital must be overcome and networks among the co-operating activities must be 
established and enhanced. Obsolete methods for organizing production must be displaced by up-to-date techniques that employ information technology equipment and software.

The output gap between the U.S. and the other G7 economies has widened since the American growth resurgence began in 1995. The G7 economies led the seven economic regions in output per capita, input per capita, and productivity throughout the period 1989-2004. Output per capita in the G7 was, nonetheless, well below U.S. levels. Taking U.S. output per capita in 2000 as $100 . \odot$, G7 output per capita was 67.2 in 1989, 73.3 in 1995, 83.3 in 2000, and 89.0 in 2004. By comparison U.S. output per capita was 79.6, 85.6, 100.0 , and 107.1 in these years.

Canada was very close to the U.S. in output per capita in 1989, but fell substantially behind by 1995 . The U.S.-Canada gap widened further during the last half of the $1990^{\prime}$ 's, despite impressive gains in Canada. Germany, Japan, Italy, and the U.K. had similar levels of output per capita throughout 1989-2004, but remained considerably behind the two North American economies. France lagged the rest of the $\mathrm{G} 7$ in output per capita in 1989 and failed to gain ground during the period 1989-2004.

The U.S. was the leader among the G7 economies in input per capita throughout the period 1989-2004. Taking the U.S. as 100.0 in 2000, G7 input per capita was 76.4 in $1989,81.2$ in $1995,89.0$ in 2000 , and 92.0 in 2004, while U.S. input per capita was 84.5, 89.2, 100.๑, and 102.5 in these years. Canada, Germany, and Japan were closest to U.S. levels of input per capita with Germany ranking second from 1989-2000 and Canada ranking second in 2004. Italy lagged behind the rest of the G7 in input per capita from 19892000 , surpassing only France in 2004. The U.K. made substantial progress toward achieving input levels comparable to those of Germany and Japan. Productivity in the $\mathrm{G} 7$ has remained close to U.S. levels, rising from 88.0 in 1989 to 90.2 in 1995, and 93.6 in 2000, and 96.8 in 2004 with the 
U.S. equal to 100.0 in 2000 . Canada was the productivity leader throughout the period 1989-2004 with the U.S. in second place, but rapidly closing the gap after 2000. Japan made substantial gains in productivity, overtaking Germany in 2000, but lagged behind the other members of the G7.

Differences among the G7 economies in output per capita can be explained by both differences in input per capita and productivity gaps. For example, the range in output in 2004 was from 69.9 for Italy to 107.1 for the U.S., while the range in input was from 76.5 for France to 102.5 for the U.S. Productivity varied from 81.7 for Germany to 105.1 for Canada. In the economies of Developing Asia output per capita rose spectacularly from 5.8 in 1989 to 8.2 in $1995,10.3$ in 2000 , and 12.7 in 2004 with the U.S. equal to 100.0 in 2000 . Levels of output per capita in Asia's largest economies, China and India, remained at 15.3 and 8.5, respectively, in 2004. These vast shortfalls in output per capita, relative to the industrialized economies, are due primarily to differences in input per capita, rather than productivity gaps. Developing Asia's levels of input per capita were 20.2 in 1989, 23.5 in 1995, 26.7 in 2000, and 29.8 in 2004, while Asian productivity levels were 28.7, 34.8, 38.5, and 42.5, respectively.

China made extraordinary gains in output per capita, growing from 4.7 in 1989 to 8.0 in $1995,11.3$ in 2000 , and 15.3 in 2004 with the U.S. equal to 100.0 in 2000 . India had essentially the same output per capita as China in 1989, but grew less impressively to only 5.8 in 1995, 7.1 in 2000, and 8.5 in 2004. China's input per capita exceeded India's throughout the period, rising to 35.8 in 2004 by comparison with India's 23.1 in the same year. India's productivity level of 26.4 in 1989 considerably exceeded China's 23.6 in that year. China's productivity rose to 30.9 in 1995, outstripping India's 30.3. China extended its lead over India in 2000 and by 
2004 had attained a productivity level of 42.7 by comparison with India's 36.7 .

Indonesia grew impressively from 1989 to 1995, but failed to recover from the Asian financial crisis of the late 1990's. Nonetheless, Indonesia maintained its lead over India in output per capita, but dropped behind China in 2000. Indonesia led India in input per capita throughout the period 1989-2004, but fell behind China in 1995. Indonesia's productivity level was ahead of both China and India in 1995, but fell behind both economies by 2000. South Korea made substantial gains in input per capita, surpassing France and approaching Italy, while falling considerably short of Japan and Germany. However, Korean productivity levels remained well below those of the G7 economies.

The 15 Non-G7 industrialized economies, taken together, had levels of output per capita, input per capita, and productivity comparable to the U.K. during period 1989-2004. Before the beginning of the transition from socialism in 1989, output per capita in Eastern Europe and the former Soviet Union was 29.๑, well above the world economy level of 18.6, with the U.S. equal to 100.0 in 2000 . The economic collapse that accompanied the transition reduced output per capita to 19.7 by 1995 , slightly below the world economy level of 19.9. A mild recovery between 1995 and 2000 brought the region back to 22.5, well below the level of 1989 and only slightly above the world economy average of 22.4 .

Input in Eastern Europe and the former Soviet Union shrank from 39.2 in 1989 to 36.3 in 1995 and then remained stagnant at 35.7 in 2000 and 36.5 in 2004. Productivity collapsed along with output per capita, declining from 74.0 in 1989 to 54.4 in 1995, before climbing back to 63.0 in 2000 and, finally, surpassing the 1989 level at 76.2 in 2004. We conclude that the transition from socialism failed to restore the region to pre-transition 
levels of output and input per capita by 2004, while productivity was only slightly higher than before the transition.

The downturn in output per capita and productivity was especially severe in the economies of the former Soviet Union. Russia's level of output per capita fell from 32.8 in 1989 to 19.8 in 1995, before recovering feebly to 21.7 in 2000 and more sharply to 28.3 in 2004 . Russian input per capita declined after 1989, but then remained essentially unchanged throughout the period 1995-2004. Russian productivity mirrored the decline and subsequent recovery in output, falling precipitously from a level of 81.6 in 1989, comparable to that of Germany and Japan, to 52.6 in 1995. Russian productivity recovered to 60.3 in 2000 and jumped to 77.5 in 2004, but remained below the 1989 level.

For the Latin American region output per capita rose from 19.4 to 22.6 during 1989-2004, input per capita rose from 28.2 to 32.7 , but productivity was essentially unchanged throughout the period at about two-thirds of the U.S. level in 2000. The stall in productivity from 1989 to 2004 was pervasive, contrasting sharply with the rise in productivity in the G7 economies, the Non-G7 industrialized economies, and Developing Asia. Nonetheless, Latin America's lagging output per capita was due chiefly to insufficient input per capita, rather than a shortfall in productivity.

Brazil's economic performance has been anemic at best and has acted as a drag on the growth of Latin America and the world economy. Despite productivity levels comparable to the rest of Latin America, Brazil was unable to generate substantial growth in input per capita. Mexico lost ground in productivity between 1989 and 2004, but made steady gains in input per capita and expanded output per capita substantially after 1995.

Output and input per capita in Sub-Sahara Africa was the lowest in the world throughout the period 1989-2004, but the level of productivity was slightly higher than that of Developing Asia until 2000. All the economies 
of North Africa and the Middle East fell short of world average levels of output and input per capita. Output per capita grew slowly but steadily for the region as a whole during 1989-2004, powered by impressive gains in input per capita and productivity.

\section{Summary and Conclusions.}

World economic growth, led by the industrialized economies and Developing Asia, experienced a strong resurgence after 1995. Developing Asia accounted for almost half of world economic growth during 1989-2004 but remained well below the world average in output per capita. Sub-Saharan Africa and North Africa and the Middle East also languished below the world average. Eastern Europe and the former Soviet Union lost enormous ground during the transition from socialism and have yet to recover completely. Growth trends apparent in the U.S. have counterparts throughout the world. Investment in tangible assets, including IT equipment and software, was the most important source of growth. However, Non-IT investment predominated. The contribution of labor input was next in magnitude with hours worked outweighing labor quality. Finally, productivity was the dominant source of growth only in Eastern Europe and the former Soviet Union during the recovery from the output and productivity collapse of 1989-1995 that accompanied the beginning of the transition from socialism to a market economy .

The leading role of IT investment in the acceleration of growth in the G7 economies is especially pronounced in the U.S. The contribution of labor input predominated in the Non-G7 industrialized economies, as well as Latin America, Eastern Europe, Sub-Saharan Africa, and North Africa and the Middle East. Productivity growth was an important source of growth in Developing Asia during the Asian Miracle before 1995, but growth of capital and labor inputs rose in importance after 1995, contrary to the "Krugman thesis". 
Productivity has been stagnant or declining in Latin America, Eastern Europe, Sub-Saharan Africa, and North Africa and the Middle East.

All seven regions of the world economy experienced a surge in investment in IT equipment and software after 1995. The impact of IT investment on economic growth was most striking in the $\mathrm{G} 7$ economies. The rush in IT investment was especially conspicuous in the U.S., but jumps in the contribution of IT capital input in Canada, Japan, and the U.K. were only slightly lower. France, Germany, and Italy also experienced a surge in IT investment, but lagged considerably behind the leaders. IT investment subsided among the G7 economies after the dot-com crash of 2000, while the contribution of Non-IT investment varied considerably and explains important differences among growth rates of the $\mathrm{G} 7$ economies.

The surge in investment in IT equipment and software is a global phenomenon, but the variation in the contribution of this investment has grown considerably since 1995. The moderation in IT investment in the industrialized countries after the dot-com crash of 2000 was accompanied by continued expansion in the contribution of IT in the developing world, especially in Asia. The contribution of IT investment more than doubled after 1995 in Developing Asia, Latin America, Eastern Europe, and North Africa and the Middle East, and Sub-Saharan Africa.

Finally, despite spectacular growth rates in Developing Asia, levels of output per capita remain below world averages. Differences in per capita output levels are mainly due to input per capita rather than productivity. This reflects the fact that technology is relatively easy to transfer from industrialized economies to developing economies, while mobilization of capital and labor inputs requires much more time and considerably greater effort. Outmoded techniques of production must give way to newer methods that incorporate the latest technologies, especially those that utilize information technology equipment and software. 
Table 1: The World Economy: Shares in Size and Growth by Economy and Region

\begin{tabular}{|c|c|c|c|c|c|c|c|c|c|}
\hline \multirow{3}{*}{ Group } & \multicolumn{3}{|c|}{ Period 1989-1995 } & \multicolumn{3}{|c|}{ Period 1995-2000 } & \multicolumn{3}{|c|}{ Period 2000-2004 } \\
\hline & \multirow{2}{*}{$\begin{array}{c}\text { GDP } \\
\text { Growth }\end{array}$} & \multicolumn{2}{|c|}{ Average Share } & \multirow{2}{*}{$\begin{array}{c}\text { GDP } \\
\text { Growth }\end{array}$} & \multicolumn{2}{|c|}{ Average Share } & \multirow{2}{*}{$\begin{array}{c}\text { GDP } \\
\text { Growth }\end{array}$} & \multicolumn{2}{|c|}{ Average Share } \\
\hline & & GDP & Growth & & GDP & Growth & & GDP & Growth \\
\hline World (110 Economies) & 2.72 & 100.00 & 100.00 & 3.73 & 100.00 & 99.99 & 3.75 & 100.00 & 99.99 \\
\hline G7 Economies & 2.15 & 49.22 & 39.69 & 3.25 & 47.24 & 41.15 & 2.20 & 45.00 & 26.44 \\
\hline Developing Asia & 7.5 & 20.06 & 55.67 & 5.91 & 24.44 & 38.67 & 6.51 & 27.31 & 47.45 \\
\hline Non-G7 & 2.08 & 9.22 & 7.05 & 2.89 & 8.97 & 6.95 & 2.91 & 8.70 & 6.76 \\
\hline Latin America & 2.92 & 8.68 & 9.34 & 2.02 & 8.41 & 4.55 & 2.94 & 7.91 & 6.20 \\
\hline Eastern Europe & -6.38 & 7.46 & -17.50 & 2.27 & 5.48 & 3.34 & 4.79 & 5.59 & 7.14 \\
\hline Sub-Sahara Africa & 1.5 & 2.21 & 1.28 & 3.26 & 2.15 & 1.88 & 3.74 & 2.13 & 2.13 \\
\hline North Africa and Middle-East & 3.9 & 3.15 & 4.59 & 3.91 & 3.31 & 3.46 & 4.30 & 3.37 & 3.87 \\
\hline
\end{tabular}

G7 (7 Economies)

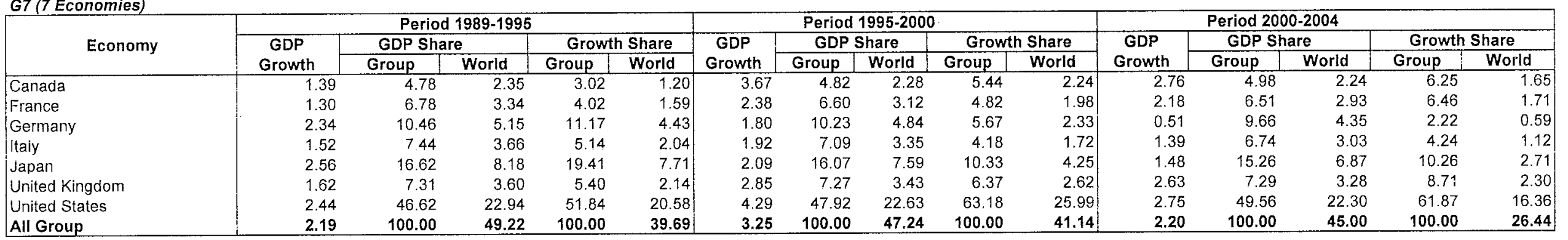

Developing and Transition Economies (7 Economies)

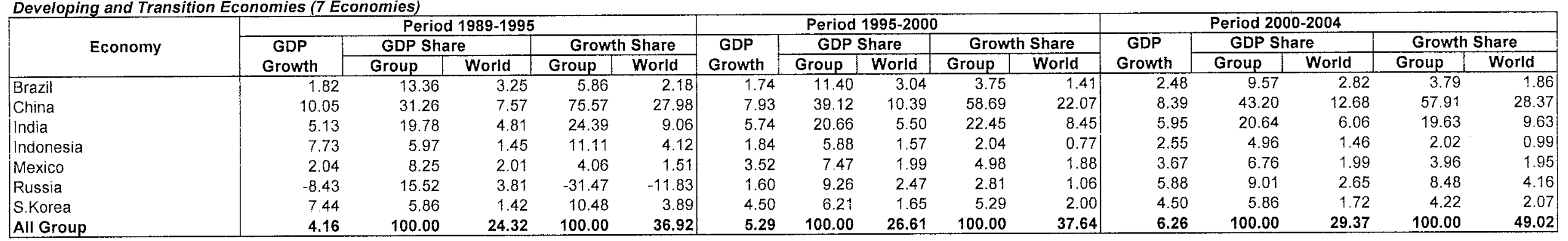


Table 2: Sources of Output Growth by period

\begin{tabular}{|c|c|c|c|c|c|c|c|c|c|c|c|c|c|c|c|c|c|c|}
\hline \multirow{4}{*}{ Economy } & \multirow{2}{*}{\multicolumn{6}{|c|}{\begin{tabular}{|c|} 
Period 1989-1995 \\
Sources of Growth (\% points per annum)
\end{tabular}}} & \multicolumn{6}{|c|}{ Period 1995-2000 } & \multicolumn{6}{|c|}{ Period 2000-2004 } \\
\hline & \multirow{3}{*}{$\begin{array}{l}\text { GDP } \\
\text { Growth }\end{array}$} & & & & & & \multirow{3}{*}{$\begin{array}{l}\text { GDP } \\
\text { Growth }\end{array}$} & \multicolumn{5}{|c|}{ Sources of Growth (\% points per annum) } & \multirow{3}{*}{$\begin{array}{l}\text { GDP } \\
\text { Growth }\end{array}$} & \multicolumn{5}{|c|}{ Sources of Growth (\% points per annum) } \\
\hline & & \multicolumn{2}{|c|}{ Capital } & \multicolumn{2}{|c|}{ Labor } & \multirow[b]{2}{*}{ TFP } & & \multicolumn{2}{|c|}{ Capital } & \multicolumn{2}{|r|}{ Labor } & \multirow[b]{2}{*}{ TFP } & & \multicolumn{2}{|c|}{ Capital } & \multicolumn{2}{|r|}{ Labor } & \multirow[b]{2}{*}{ TFP } \\
\hline & & ICT & Non-ICT & Hours & Quality & & & $\mathrm{ICT}$ & Non-ICT & Hours & Quality & & & ICT & Non-ICT & Hours & Quality & \\
\hline World (110 Economies) & 2.72 & 0.26 & 0.87 & 0.53 & 0.45 & 0.61 & 3.73 & 0.55 & 0.96 & 0.92 & 0.34 & 0.96 & 3.75 & 0.42 & 0.86 & 0.70 & 0.37 & 1.40 \\
\hline G7 & 2.19 & 0.39 & 9 & 0.07 & 0.43 & 0.42 & 3.25 & 0.82 & 0.87 & 0.63 & 0.24 & 0.69 & 2.20 & 0.47 & 0.58 & 0.08 & 0.28 & 0.70 \\
\hline Developing Asia & 7.54 & 0.14 & 37 & 1.80 & 0.53 & 3.41 & 5.91 & 0.33 & 1.89 & .17 & .47 & 2.04 & 6.51 & 0.44 & 1.83 & 1.20 & 0.48 & 2.57 \\
\hline Non-C & 2.08 & 0.14 & & 0.40 & 0.28 & 0.85 & 2.89 & 0.31 & 0.50 & 1.60 & 0.26 & 0.23 & 2.91 & 0.27 & 0.52 & 1.48 & 0.26 & 0.37 \\
\hline Latin $A$ & 2.92 & 0.14 & 0.52 & 1.31 & 0.46 & 0.49 & 2.02 & 0.29 & 0.66 & 1.29 & 0.41 & -0.62 & 2.94 & 0.30 & 0.57 & 1.41 & 0.41 & 0.25 \\
\hline Eastern Europe & -6.38 & 0.09 & -0.15 & $-1,75$ & 0.45 & -5.01 & 2.27 & 0.23 & -0.85 & -0.31 & 0.43 & 2.77 & 4.79 & 0.31 & -0.50 & -0.12 & 0.46 & 4.65 \\
\hline Sub-Saharan Africa & 1.57 & 0.10 & 0.20 & 2.19 & 0.70 & -1.62 & 3.26 & 0.23 & 0.43 & 1.86 & 0.51 & 0.24 & 3.74 & 0.27 & 0.54 & 1.54 & 0.51 & 0.88 \\
\hline N. Africa \& M. East & 3.97 & 0.15 & 0.65 & 1.99 & 0.68 & 0.51 & 3.91 & 0.30 & 0.78 & 1.85 & 0.60 & 0.37 & 4.30 & 0.42 & 0.72 & 2.22 & 0.60 & 0.34 \\
\hline
\end{tabular}

\begin{tabular}{|c|c|c|c|c|c|c|c|c|c|c|c|c|c|c|c|c|c|c|}
\hline \multirow{4}{*}{ Economy } & \multicolumn{6}{|c|}{ Period 1989-1995 } & \multicolumn{6}{|c|}{ Period 1995-2000 } & \multicolumn{6}{|c|}{ Period 2000-2004 } \\
\hline & \multirow{3}{*}{$\begin{array}{l}\text { GDP } \\
\text { Growth }\end{array}$} & \multicolumn{5}{|c|}{ Sources of Growth (\% points per annum) } & \multirow{3}{*}{\begin{tabular}{c|} 
GDP \\
Growth
\end{tabular}} & \multicolumn{5}{|c|}{ Sources of Growth (\% points per annum) } & \multirow{3}{*}{$\begin{array}{c}\text { GDP } \\
\text { Growth }\end{array}$} & \multicolumn{5}{|c|}{ Sources of Growth (\% points per annum) } \\
\hline & & \multicolumn{2}{|c|}{ Capital } & \multicolumn{2}{|c|}{ Labor } & \multirow[b]{2}{*}{ TFP } & & \multicolumn{2}{|c|}{ Capital } & \multicolumn{2}{|r|}{ Labor } & \multirow[b]{2}{*}{ TFP } & & \multicolumn{2}{|c|}{ Capital } & \multicolumn{2}{|r|}{ Labor } & \multirow[b]{2}{*}{ TFP } \\
\hline & & ICT & Non-ICT & Hours & Quality & & & ICT & Non-ICT & Hours & Quality & & & ICT & Non-ICT & Hours & Quality & \\
\hline Canada & 1.39 & 0.49 & 0.27 & 0.08 & 0.55 & 0.00 & 3.67 & 0.94 & 0.77 & 1.08 & 0.21 & 0.66 & 2.76 & 0.45 & 0.67 & 1.29 & 0.15 & 0.20 \\
\hline France & 1.30 & 0.20 & 0.92 & -0.17 & 0.61 & -0.26 & 2.38 & 0.39 & 0.81 & 0.45 & 0.35 & 0.37 & 2.18 & 0.37 & 0.29 & 0.64 & -0.08 & 0.97 \\
\hline Germany & 2.34 & 0.28 & 1.03 & -0.41 & 0.33 & 1.12 & 1.80 & 0.44 & 0.92 & -0.03 & 0.21 & 0.25 & 0.51 & 0.34 & -0.20 & 0.09 & 0.18 & 0.10 \\
\hline Italy & 1.52 & 0.26 & 0.85 & -0.35 & 0.38 & 0.37 & 1.92 & 0.48 & 1.00 & 0.55 & 0.46 & -0.58 & 1.39 & 0.36 & 0.66 & 0.75 & 0.21 & -0.58 \\
\hline Japan & 2.56 & 0.31 & 1.16 & -0.39 & 0.54 & 0.94 & 2.09 & 0.78 & 0.38 & -0.42 & 0.26 & 1.10 & 1.48 & 0.31 & 0.21 & -0.32 & 0.21 & 1.06 \\
\hline United Kingdom & 1.62 & 0.29 & 1.67 & -0.72 & 0.49 & -0.11 & 2.85 & 0.79 & 0.20 & 0.61 & 0.33 & 0.93 & 2.63 & 0.57 & 0.54 & 0.65 & 0.27 & 0.59 \\
\hline United States & 2.44 & 0.49 & 0.71 & 0.57 & 0.37 & 0.30 & 4.29 & 1.02 & 1.11 & 1.12 & 0.19 & 0.84 & 2.75 & 0.57 & 0.86 & -0.16 & 0.40 & 1.08 \\
\hline All Group & 2.19 & 0.39 & 0.89 & 0.07 & 0.43 & 0.42 & 3.25 & 0.82 & 0.87 & 0.63 & 0.24 & 0.69 & 2.20 & 0.47 & 0.58 & 0.08 & 0.28 & 0.79 \\
\hline
\end{tabular}

Developing and Transition Economies ( 7 Economies)

\begin{tabular}{|c|c|c|c|c|c|c|c|c|c|c|c|c|c|c|c|c|c|c|}
\hline \multirow{4}{*}{ Economy } & \multicolumn{6}{|c|}{ Period 1989-1995 } & \multicolumn{6}{|c|}{ Period 1995-2000 } & \multicolumn{6}{|c|}{ Period 2000-2004 } \\
\hline & \multirow{3}{*}{$\begin{array}{c}\text { GDP } \\
\text { Growth }\end{array}$} & \multicolumn{5}{|c|}{ Sources of Growth (\% points per annum) } & \multirow{3}{*}{$\begin{array}{c}\text { GDP } \\
\text { Growth }\end{array}$} & \multicolumn{5}{|c|}{ Sources of Growth (\% points per annum) } & \multirow{3}{*}{$\begin{array}{l}\text { GDP } \\
\text { Growth }\end{array}$} & \multicolumn{5}{|c|}{ Sources of Growth (\% points per annum) } \\
\hline & & \multicolumn{2}{|c|}{ Capital } & \multicolumn{2}{|c|}{ Labor } & \multirow[b]{2}{*}{ TFP } & & \multicolumn{2}{|c|}{ Capital } & \multicolumn{2}{|c|}{ Labor } & \multirow[b]{2}{*}{ TFP } & & \multicolumn{2}{|c|}{ Capital } & \multicolumn{2}{|r|}{ Labor } & \multirow[b]{2}{*}{ TFP } \\
\hline & & $\mathrm{ICT}$ & Non-ICT & Hours & Quality & & & ICT & Non-ICT & Hours & Quality & & & ICT & Non-ICT & Hours & Quality & \\
\hline Brazil & 1.82 & 0.07 & 0.22 & 0.94 & 0.53 & 0.06 & 1.74 & 0.25 & 0.21 & 0.96 & 0.50 & -0.18 & 2.48 & 0.27 & 0.05 & 1.01 & 0.49 & 0.64 \\
\hline China & 10.05 & 0.17 & 2.21 & 2.56 & 0.56 & 4.55 & 7.93 & 0.48 & 2.69 & 0.82 & 0.48 & 3.46 & 8.39 & 0.63 & 2.73 & 0.81 & 0.48 & 3.73 \\
\hline India & 5.13 & 0.08 & 1.12 & 1.10 & 0.56 & 2.28 & 5 & 0.17 & 1.39 & 1.59 & 0.53 & 2.07 & 5.95 & 0.26 & 1.39 & 1.58 & 0.53 & 2.20 \\
\hline Indonesia & 7.73 & 0.07 & 1.42 & 1.18 & 0.57 & 4.50 & 1.84 & 0.06 & 1.10 & 1.50 & 0.55 & -1.37 & 2.55 & 0.08 & 0.50 & 1.42 & 0.57 & -0.02 \\
\hline Mexico & 2.04 & 0.25 & 1.03 & 1.56 & 0.38 & -1.18 & 3.52 & 0.29 & 1,32 & 1.52 & 0.31 & 0.08 & 3.67 & 0.28 & 1.63 & 1.67 & 0.32 & -0.23 \\
\hline Russia & -8.43 & 0.06 & -0.07 & -1.57 & 0.47 & -7.31 & 1.60 & 0.10 & $-1,62$ & -0.10 & 0.50 & 2.72 & 5.88 & 0.15 & -1.09 & -0.01 & 0.56 & 6.28 \\
\hline S.Korea & 7.44 & 0.21 & 2.02 & 2.00 & 0.41 & 2.79 & 4.50 & 0.34 & 1.30 & 0.80 & 0.34 & 1.72 & 4.50 & 0.39 & 0.84 & 1.20 & 0.34 & 1.74 \\
\hline All Group & 4.16 & 0.12 & 1.22 & 1.21 & 0.52 & 1.08 & 5.29 & 0.31 & 1.46 & 1.00 & 0.48 & 2.04 & 6.26 & 0.41 & 1.56 & 1.03 & 0.48 & 2.78 \\
\hline
\end{tabular}


Table 3: Levels of Output and Input Per Capita and Productivity (U.S $=100$ in 2000)

* The levels for group and the world are averages weighted by population share

Group Summaries

\begin{tabular}{|c|c|c|c|c|c|c|c|c|c|c|c|c|}
\hline \multirow[t]{2}{*}{ Country } & \multicolumn{4}{|c|}{ Output Per Capita } & \multicolumn{4}{|c|}{ Input Per Capita } & \multicolumn{4}{|c|}{ Productivity } \\
\hline & 1989 & 1995 & 2000 & 2004 & 1989 & 1995 & 2000 & 2004 & 1989 & 1995 & 2000 & 2004 \\
\hline World & 18.6 & 19.9 & 22.4 & 24.9 & 30.5 & 32.5 & 35.3 & 37.7 & 61.0 & 61.2 & 63.5 & 66.0 \\
\hline G7 & 67.2 & 73.3 & 83.3 & 89.0 & 76.4 & 81.2 & 89.0 & 92.0 & 88.0 & 90.2 & 93.6 & 96.8 \\
\hline Developing Asia & 5.8 & 8.2 & 10.3 & 12.7 & 20.2 & 23.5 & 26.7 & 29.8 & 28.7 & 34.8 & 38.5 & 42.5 \\
\hline Non-G7 & 57.1 & 62.1 & 69.5 & 75.7 & 63.4 & 65.5 & 72.0 & 77.2 & 90.0 & 94.9 & 96.4 & 98.1 \\
\hline Latin America & 19.4 & 20.8 & 21.3 & 22.6 & 28.2 & 29.5 & 31.1 & 32.7 & 68.8 & 70.6 & 68.4 & 69.1 \\
\hline Eastern Europe & 29.0 & 19.7 & 22.5 & 27.8 & 39.2 & 36.3 & 35.7 & 36.5 & 74.0 & 54.4 & 63.0 & 76.2 \\
\hline Sub-Sahara Africa & 5.5 & 5.1 & 5.3 & 5.6 & 13.1 & 13.5 & 14.0 & 14.7 & 41.5 & 37.7 & 37.7 & 38.4 \\
\hline N. Africa \& M. East & 11.0 & 12.2 & 13.5 & 15.0 & 20.3 & 21.9 & 23.8 & 25.9 & 54.2 & 55.7 & 56.9 & 57.9 \\
\hline
\end{tabular}

G7 (7 Economies)

\begin{tabular}{|c|c|c|c|c|c|c|c|c|c|c|c|c|}
\hline \multirow[t]{2}{*}{ Economy } & \multicolumn{4}{|c|}{ Output Per Capita } & \multicolumn{4}{|c|}{ Input Per Capita } & \multicolumn{3}{|c|}{ Productivity } & \multirow[b]{2}{*}{2004} \\
\hline & 1989 & 1995 & 2000 & 2004 & 1989 & 1995 & 2000 & 2004 & 1989 & 1995 & 2000 & \\
\hline Canada & 76.0 & 77.0 & 88.3 & 94.9 & 75.3 & 76.3 & 84.6 & 90.2 & 100.9 & 100.9 & 104.3 & 105.1 \\
\hline France & 60.0 & 63.3 & 69.9 & 74.7 & 64.1 & 68.7 & 74.5 & 76.5 & 93.5 & 92.1 & 93.9 & 97.6 \\
\hline Germany & 59.7 & 66.3 & 72.0 & 73.2 & 79.4 & 82.5 & 88.5 & 89.7 & 75.1 & 80.3 & 81.4 & 81.7 \\
\hline Italy & 55.7 & 60.5 & 66.0 & 69.9 & 61.4 & 65.2 & 73.2 & 79.3 & 90.8 & 92.9 & 90.2 & 88.2 \\
\hline Japan & 57.4 & 65.2 & 70.8 & 75.1 & 76.0 & 82.2 & 85.1 & 86.6 & 75.5 & 79.3 & 83.2 & 86.8 \\
\hline United Kingdom & 59.9 & 65.0 & 74.2 & 81.4 & 65.6 & 71.6 & 78.0 & 83.6 & 91.4 & 90.8 & 95.1 & 97.4 \\
\hline United States & 79.6 & 85.6 & 100.0 & 107.1 & 84.5 & 89.2 & 100.0 & 102.5 & 94.2 & 95.9 & 100.0 & 104.4 \\
\hline All Group & 67.2 & 73.3 & 83.3 & 89.0 & 76.4 & 81.2 & 89.0 & 92.0 & 88.0 & 90.2 & 93.6 & 96.8 \\
\hline
\end{tabular}

Developing and Transition Economies (7 Economies)

\begin{tabular}{|c|c|c|c|c|c|c|c|c|c|c|c|c|}
\hline \multirow[t]{2}{*}{ Economy } & \multicolumn{4}{|c|}{ Output Per Capita } & \multicolumn{4}{|c|}{ Input Per Capita } & \multicolumn{4}{|c|}{ Productivity } \\
\hline & 1989 & 1995 & 2000 & 2004 & 1989 & 1995 & 2000 & 2004 & 1989 & 1995 & 2000 & 2004 \\
\hline Brazil & 20.9 & 21.2 & 21.6 & 22.6 & 31.8 & 32.3 & 33.2 & 33.8 & 65.5 & 65.7 & 65.1 & 66.8 \\
\hline China & 4.7 & 8.0 & 11.3 & 15.3 & 19.8 & 25.7 & 30.7 & 35.8 & 23.6 & 30.9 & 36.8 & 42.7 \\
\hline India & 4.8 & 5.8 & 7.1 & 8.5 & 18.1 & 19.1 & 21.0 & 23.1 & 26.4 & 30.3 & 33.6 & 36.7 \\
\hline Indonesia & 6.2 & 9.0 & 9.2 & 9.7 & 22.8 & 25.1 & 27.6 & 28.9 & 27.3 & 35.8 & 33.4 & 33.4 \\
\hline Mexico & 22.7 & 23.0 & 25.5 & 27.8 & 28.5 & 31.0 & 34.2 & 37.6 & 79.7 & 74.3 & 74.6 & 73.9 \\
\hline Russia & 32.8 & 19.8 & 21.7 & 28.3 & 40.2 & 37.6 & 36.1 & 36.5 & 81.6 & 52.6 & 60.3 & 77.5 \\
\hline S.Korea & 25.5 & 37.5 & 45.0 & 52.6 & 46.7 & 58.1 & 64.0 & 69.7 & 54.6 & 64.5 & 70.3 & 75.4 \\
\hline All Group & 8.3 & 9.7 & 11.8 & 14.5 & 22.0 & 25.2 & 28.2 & 31.3 & 37.6 & 38.4 & 41.9 & 46.4 \\
\hline
\end{tabular}




\section{References.}

Ahmad, Nadim, Paul Schreyer, and Anita Wolfl (2004), "ICT Investment in OECD Countries and Its Economic Impact," Chapter 4 in OECD, The Economic Impact of ICT: Measurement, Evidence, and Implications, Paris: Organization for Economic Co-operation and Development.

Baldwin, John R., and Tarek M. Harchaoui (2003), Productivity Growth in Canada - 2002, Ottawa: Statistics Canada.

Barro, Robert J., and Jong-Wha Lee (2001), "International Data on Educational Attainment: Updates and Implications," Oxford Economic Papers, Vol. 53, No. 4, July, pp. 541-563.

Business Software Alliance (2006), Global Software Piracy Study: Washington, DC: Business Software Alliance USA, May. See: http://www.bsa.org/usa/research/loader.cfm?url=/commonspot/utilities/handlelink . cfm\&thelink=CP_PAGEID $=16808$, index . $\mathrm{cfm}, 443$.

Daveri, Francesco (2002), "The New Economy in Europe: 1992-2001," Oxford Review of Economic Policy, Vol. 18, No. 4, September, pp. 345-362.

Grimm, Bruce, Brent Moulton, and David Wasshausen (2005), "Information Processing Equipment and Software in the National Accounts," in Carol Corrado, John Haltiwanger, and Daniel Sichel, eds., Measuring Capital in the New Economy, Chicago, IL: University of Chicago Press, pp. 363-402.

Heston, Alan, Robert Summers, and Bettina Aten (2002), Penn World Table Version 6.1, Philadelphia, PA: Center for International Comparisons at the University of Pennsylvania (CICUP), October. See:

http://pwt . econ. upenn. edu/aboutpwt. html.

Holz, Carsten A. (2006), “China's Reform Period Economic Growth: How Reliable Are Angus Maddison's Estimates?" Review of Income and Wealth, Series 52, No. 1, March, pp. 85-120. 
International Telecommunications Union (2006), World Telecommunications Indicators Database, $9^{\text {th }}$ edition, Geneva: International Telecommunications Union, April. See: http://WWW.itu.int/ITU D/ict/publications/world/world.html. Jorgenson, Dale W. (2001), "Information Technology and the U.S. Economy," American Economic Review, Vol. 91, No. 1, March, pp. 1-32. (2003), "Information Technology and the G7 Economies," World

Economics, Vol. 4, No. 4, October-December, pp. 139-170.

Jorgenson, Dale W. (2005), "Accounting for Growth in the Information Age," in Philippe Aghion and Steven Durlauf, Handbook of Economic Growth, Amsterdam, North-Holland, pp. 743-815.

Jorgenson, Dale W., Mun S. Ho, and Kevin J. Stiroh (2005), Information Technology and the American Growth Resurgence, Cambridge, The MIT Press. Jorgenson, Dale W., and Kazuyuki Motohashi (2005), "Information Technology and the Japanese Economy," Journal of the Japanese and International Economies, Vol. 19, No. 4, December, pp. 460-481. Jorgenson, Dale W., and Kevin J. Stiroh (2000), "Raising the speed Limit: U.S. Economic Growth in the Information Age," Brookings Papers on Economic Activity, 1, pp. 125-211.

Jorgenson, Dale W., and Eric Yip (2000), "Whatever Happened to Productivity Growth?" in Charles R. Hulten, Edwin R. Dean, and Michael J. Harper, eds., New Developments in Productivity Analysis, Chicago, IL: University of Chicago Press, pp. 509-540.

Kaufmann, Daniel, Aart Kray, and Massimo Mastruzzi (2004), “Governance Matters III: Governance Indicators for 1996-2002," Washington, DC: World Bank, April. See:

http://www.worldbank.org/wbi/governance/pdf/govmatters3_wber.pdf.

Krugman, Paul (1994), "The Myth of Asia's Miracle," Foreign Affairs, Vol. 73, No. 6, November/December, pp. 62-78. 
Lau, Lawrence J. (1999), "The Sources of East Asian Economic Growth," in Gustav Ranis, Sheng-Cheng $\mathrm{Hu}$, and Yun-Peng Chu, The Political Economy of Comparative Development in the $21^{\text {st }}$ Century, Northampton, MA, Edward Elgar, pp. $45-75$.

Maddison, Angus (1998), China's Economic Performance in the Long Run, Paris, Organization for Economic Co-operation and Development. (2001), The World Economy: A Millenial Perspective, Paris, Organization for Economic Co-operation and Development. (2006), “Do Official Statistics Exaggerate China's GDP Growth? A Reply to Carsten Holz," Review of Income and Wealth, Series 52, No. 1, March, pp. 121-126.

Organization for Economic Co-operation and Development (2005), Purchasing Power Parities and Real Expenditures, 2002 Benchmark Year, Paris, Organization for Economic Co-operation and Development. See:

http://Www. sourceoecd.org.

Oliner, Stephen D., and Daniel J. Sichel (2000), "The Resurgence of Growth in the Late 1990's: Is Information Technology the Story?" Journal of Economic Perspectives, Vol. 14, No. 4, Fall, pp. 3-22.

Piatkowski, Marcin, and Bart van Ark (2005), "ICT and Productivity Growth in Transition Economies: Two-Phase Convergence and Structural Reforms," TIGER Working Paper Series No. 72, Warsaw, January 2005. See: http://Www.tiger.edu.pl/publikacje/TWPNo72.pdf.

Timmer, Marcel P., Gerard Ypma, and Bart van Ark (2003, updated 2005), IT in the European Union: Driving Productivity Divergence? GGDC Research Memordandum GD-67, Groningen, University of Groningen, October. March. See: http://WwW.ggdc.net/workpap.html.

United Nations (2005), Human Development Report 2005, New York, NY: United Nations. See: http://hdr.undp.org/. 
World Bank (2006), World Development Indicators 2006, Washington, DC:

World Bank. See: http://www.worldbank.org/data/wdi2004/index.htm. World Information Technology and Services Alliance, Digital Planet Report (2006), Washington, DC, World Information Technology and Services Alliance. See: http://www.witsa.org/.

Young, Alwyn (1995), The Tyranny of Numbers: Confronting the Statistical Realities of the East Asian Growth Experience," Quarterly Journal of Economics, Vol. 106, No. 1, August, pp. 641-680. (2003), “Gold into Base Metals: Productivity Growth in the People's Republic of China during the Reform Period," Journal of Political Economy, Vol. 111, No. 6, December, pp. 1220-1261. 